\title{
Effects of prescribed fire on surface soil in a Pinus pinaster plantation, northern Portugal
}

\author{
A. Meira-Castro - R. A. Shakesby - J. Espinha Marques · \\ S. H. Doerr · J. P. Meixedo · J. Teixeira . \\ H. I. Chamine'
}

\begin{abstract}
In order to decrease the risk of severe wildfire, prescribed fire has recently been adopted in Portugal and elsewhere in the Mediterranean as a major tool for reducing the fuel load instead of manual or mechanical removal of vegetation. There has been some research into its impact on soils in shrublands and grasslands, but to date little research has been conducted in forested areas in the region. As a result, the impact of prescribed fire on the physico-chemical soil characteristics of forest soils has been assumed to be minimal, but this has not been demonstrated. In this study, we present the results of a monitoring campaign of a detailed pre- and post-prescribed fire assessment of soil properties in a long-unburnt $P$. pinaster plantation, NW Portugal. The soil characteristics examined were $\mathrm{pH}$, total porosity, bulk density, moisture content, organic matter content and litter/ash quantity. The results show that there was no significant impact on the measured soil properties, the only effect being confined to minor changes in the upper $1 \mathrm{~cm}$ of soil. We conclude that provided the fire is
\end{abstract}

carried out according to strict guidelines in $P$. pinaster forest, a minimal impact on soil properties can be expected.

Keywords

Prescribed fire · Pinus pinaster forest - Soil disturbance

- Soil quality $\cdot$ NW Portugal

\section{Introduction}

In hot and dry summer months, the often large highly flammable fuel load (i.e. the dead and live biomass available for combustion) in many Mediterranean forests and woodlands, combined with high air temperatures, low relative air humidity and strong winds, can leave these areas prone to wildfire events (e.g. Pausas et al. 2008). In view of the rise in wildfire activity in the last decades with its significant impacts on water-soil-plant ecosystems and people, some Mediterranean countries have recently adopted prescribed fire carried out in autumn and spring as one of the most effective forest management tools for fuel load reduction (Fernandes and Botelho 2003, 2004). In Portugal, there has been a long history of using prescribed fire in grass and shrub vegetation to improve pasture (Moreira et al. 2003; Rodrigues 1999). Its use as a means of controlling fuel load, however, has only relatively recently been adopted following particularly severe wildfire activity on mainland Portugal in the early 2000s (Salgueiro 2010). It is now the preferred option for fuel load reduction in order to mitigate the severe wildfire risk. Since 2006, both public bodies and private landowners have been able legally to use this practice (AFN 2006). Its popularity compared with manual or mechanical removal of ground vegetation and litter is based on it being less labourintensive and thus less expensive (Aguilar and Montiel 2011). Recent use of prescribed fire in Portugal has 
primarily been focused on controlling the fuel load in shrublands (Meira-Castro et al. 2011, 2012), but under well-controlled conditions, it can also be used in mature pine forests for the same purpose, though this application to date has proved less common. In fact, even for the specialist personnel using the technique under strict guidelines to prevent tree loss, it is a complex, skilled task, and a successful outcome reaching all the objectives may often not be achievable. Some studies have reported that any soil heating resulting from prescribed fire does not substantially modify soil properties (e.g. Úbeda et al. 2005), whereas others have reported that soil physical and chemical properties are significantly changed, in addition to the changes in biota, and susceptibility to loss of soil and nutrients (e.g., Botelho et al. 1998; Moreira et al. 2003; Carter and Foster 2004; Fernandes and Botelho 2004).

To date, Portuguese authorities have believed that, from the cost-benefit viewpoint, forest vegetation reduction using prescribed fire should only be carried out where mechanical removal of vegetation is difficult, although there has been insufficient research to indicate the long-term sustainability or otherwise of the use of prescribed fire.

The aim of this study is to address this research gap by examining the impact of a prescribed fuel reduction burn on selected environmentally relevant soil characteristics ( $\mathrm{pH}$, total porosity, moisture content, bulk density, organic matter content, litter and ash quantity) and tree mortality in a 20-year-old pine (Pinus pinaster) plantation near Tresminas, northern Portugal, determined before and immediately after burning.

\section{Materials and methods}

The study site

The Tresminas study site $\left(41829^{0} 18^{00} \mathrm{~N} ; 7831^{0} 11^{00} \mathrm{~W}\right)$ is an $\mathrm{N}-\mathrm{S}$ aligned area with approximately $600 \mathbf{9} 120 \mathrm{~m}$ and a mean slope angle of 78 gently dipping to the WSW

(Fig. 1). The vegetation comprises a 20-year-old Pinus pinaster stand with an understorey of mainly broom (Pterospartum tridentatum; 60-80 cm high) and patches of heather (Erica spp.; c. $50 \mathrm{~cm}$ high). Prior to burning, the litter layer consisted mostly of pine needles and was up to c. $5 \mathrm{~cm}$ thick. The bedrock comprises Devonian phyllites and metagreywackes in the northern half giving way to Silurian phyllites and schists interrupted by bands of lyddites in the south (Sant'Ovaia et al. 2011).

The study site lies on Padrela Mountain on a plateau surface that slopes gently NNE-SSW from 870 to $750 \mathrm{~m}$. Soil type, according to the IUSS Working Group WRB (2006) classification, varies from Umbric Leptosol with some bedrock outcrops in the north to thicker Umbric
Cambisol in the south. Soil colour, texture and porosity together with moisture conditions immediately prior to the burn are given in Fig. 1.

The climate can be described as wet Mediterranean, with cool wet winters and warm dry summers. The mean annual temperature at the study site is c. $11{ }^{\circ} \mathrm{C}$. Mean annual rainfall at Vila Pouca de Aguiar $(10 \mathrm{~km}$ west of Tresminas, at $750 \mathrm{~m}$ a.s.1.) is c. $1,500 \mathrm{~mm}$.

The prescribed fire

In February 2011, the site was subject to a prescribed fire, which was carefully controlled as regards its propagation speed, the size of the flame front and the fire intensity (energy emitted per unit area). Burning commenced in the early morning when the air humidity was still high, the plants relatively moist and the air temperature low. At the beginning, midway and end of the $14 \mathrm{~h}$ during which the prescribed fire was conducted, air temperature $(10.7,12.3$ and 8.58C), humidity $(73.1,68.0$ and $78.3 \%)$ and wind speed and direction (1.9 and $4.9 \mathrm{~m} \mathrm{~s}^{-1}$; direction constant at $\mathrm{W}-\mathrm{E}$ ) were recorded. The maximum flame height was restricted to 80-90 cm. Greater flame heights were avoided as they might have led to widespread tree damage. The fire spread at the rate of $10-15 \mathrm{~m} \mathrm{~h}^{-1}$. When the burning conditions led to an increase in this speed, the fire patrol personnel dowsed the vegetation with water to slow down the rate of spread. The burning method used was modified as meteorological conditions changed during the course of the operation. The entire burn took an unusually long time to complete because wind speed remained so low. This had the benefit, however, of enabling a more complete combustion of the vegetation and litter, which involved several ignition lines arranged parallel with the contour (Meira-Castro et al. 2014).

\section{Sampling and laboratory work}

To assess the impact of the prescribed fire on the soil, certain key soil physico-chemical parameters were selected for measurement: $\mathrm{pH}$, bulk density, total porosity, moisture content, and organic matter content. Soil sampling was carried out at 17 points spread in a grid over the study site (Fig. 2).

At each soil sampling point, a $1 \mathrm{~m}^{2}$ plot was marked out, and soil samples collected and measurements made before and immediately after the fire. Sampling was carried out according to internationally recognised standards (ISO 10381-1 and ISO 10381-2). The following pre- and postfire soil sampling and in situ and laboratory measurements were undertaken. First, at each sampling point, immediately before the fire, all litter ( $\mathrm{O}$ horizon) were removed from a $25925 \mathrm{~cm}$ subplot to determine the forest-floor potential fuel load. After the fire, on a separate subplot, the quantities of ash as well as unburnt and charred litter were 


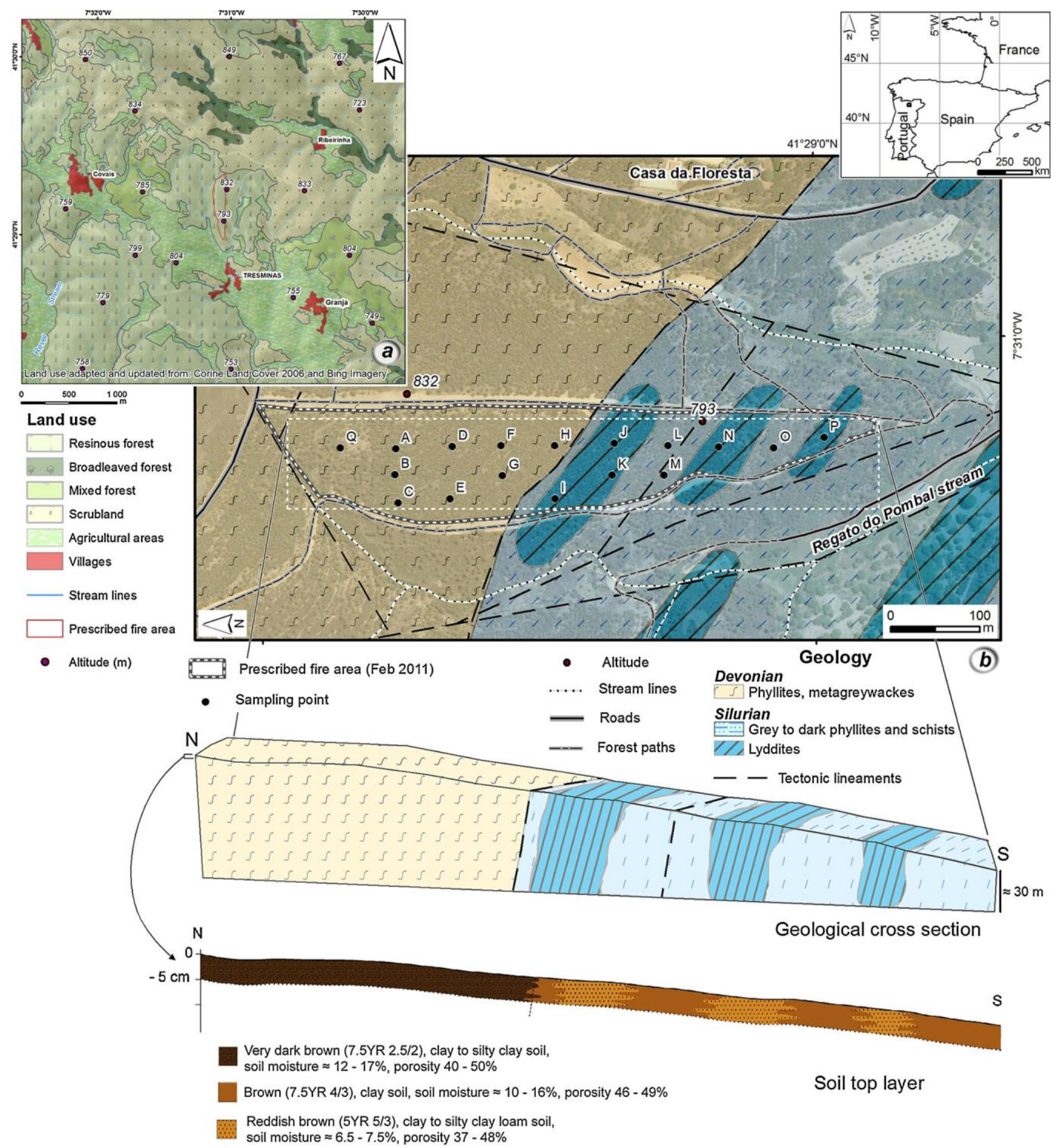

Fig. 1 The Tresminas study site in northern Portugal: a aspects of the relief together with land use in the surrounding area (adapted from Agroconsultores and COBA 1991); b sampling points together with

collected. Second, soil volumetric moisture content was measured in the upper $5 \mathrm{~cm}$ of the mineral soil (A horizon) using a Thetaprobe (model ML2X). Third, undisturbed soil samples were collected from the same layer (upper $5 \mathrm{~cm}$ of A horizon) to estimate the total porosity and bulk density. geology and soil characteristics (regional geology background updated from Sant'Ovaia et al. 2011)

Finally, samples of mineral soil (A horizon) from 0 to $1 \mathrm{~cm}$ and 1 to $5 \mathrm{~cm}$ were collected for laboratory measurements of $\mathrm{pH}$ and organic matter content.

Analytical procedures followed international standard methods (ISO 11464:2006 for pre-treatment of soil samples 
for physico-chemical analysis, ISO 11465:1993 and ISO 10694:1995 for the determination of organic matter using a TOC-VcsnShimadzu equipment) and the method described by Hendershot et al. (2008) for measuring soil $\mathrm{pH}$ in water (in a 2:1 deionized water/mineral soil suspension).

Analysis of residual values performed according to Shapiro-Wilk's and Levene's tests showed that ANOVA assumptions of normality and homoscedasticity were not met (Lix et al. 1996). Hence, Kruskal-Wallis non-parametric analyses of variance were applied to test the null hypothesis, that the fire had no significant effect on each of the parameters investigated. A data rank transformation was applied to the entire set of observations from smallest to largest, and the usual parametric procedure was then applied to the ranked rather than raw data (Conover and Iman 1981). A threshold significance level of $5 \%$ ( $p$ B 0.05 ) was used. In the cases where the null hypothesis was rejected, multiple comparisons of the factors were performed using the Tukey-HSD post hoc test.

\section{Results}

Table 1 and Fig. 3 summarise pre- and post-fire values for soil solution $\mathrm{pH}$, organic matter content, soil moisture, total porosity, bulk density and litter and ash cover. The soil was

Table 1 Pre- and post-fire values for mean, median, range and standard deviation for selected soil characteristics at different soil depths at the sampling points $(n=17)$

\begin{tabular}{|c|c|c|c|c|c|}
\hline & $\begin{array}{l}\text { Sample timing } \\
\text { and depth }\end{array}$ & Mean & Median & Range & SD \\
\hline \multirow[t]{4}{*}{$\mathrm{pH}$} & BF:0-1 & 4.5 & 4.4 & 1.8 & 5.7 \\
\hline & $A F: 0-1$ & 4.6 & 4.6 & 0.7 & 4.9 \\
\hline & BF:1-5 & 4.8 & 4.7 & 1 & 5.4 \\
\hline & $A F: 1-5$ & 4.8 & 4.9 & 1.2 & 5.6 \\
\hline \multirow{4}{*}{$\begin{array}{l}\text { Organic matter } \\
(\%)\end{array}$} & BF:0-1 & 10 & 9.9 & 9.7 & 16.1 \\
\hline & $A F: 0-1$ & 9.7 & 9.7 & 5.3 & 12.7 \\
\hline & BF:1-5 & 6.9 & 6.8 & 7.4 & 11.0 \\
\hline & $A F: 1-5$ & 7.4 & 7.7 & 4.6 & 9.5 \\
\hline \multirow{2}{*}{$\begin{array}{l}\text { Soil moisture } \\
\text { (1n situ) (\%) }\end{array}$} & BF:0-5 & 11.8 & 12.3 & 10.5 & 17 \\
\hline & $A F: 0-5$ & 11.4 & 10.5 & 13.9 & 18.5 \\
\hline \multirow{2}{*}{$\begin{array}{l}\text { Total porosity } \\
(\%)\end{array}$} & BF:0-5 & 44.5 & 46.3 & 16.2 & 52.3 \\
\hline & $A F: 0-5$ & 47.8 & 46.6 & 43.5 & 70.6 \\
\hline \multirow{2}{*}{$\begin{array}{l}\text { Bulk density } \\
\qquad\left(\mathrm{g} \mathrm{cm}^{-\lrcorner}\right)\end{array}$} & BF:0-5 & 1.4 & 1.4 & 0.6 & 1.7 \\
\hline & $A F: 0-5$ & 1.4 & 1.4 & 0.4 & 1.6 \\
\hline \multirow{2}{*}{$\begin{array}{l}\text { Litter/ash } \\
\left(\mathrm{g} \mathrm{m}^{-2}\right)\end{array}$} & BF:5-0 & 300.7 & 299.9 & 232.7 & 72.2 \\
\hline & $A F: 5-0$ & 12.9 & 10.2 & 21.8 & 7.5 \\
\hline
\end{tabular}

$B F$ before fire, $A F$ after fire; $0-1$ and $1-5 \mathrm{~cm}$ below surface except for litter and ash which were collected from the soil surface; $0 \mathrm{~cm}$ corresponds to the surface between $\mathrm{O}$ horizon and $\mathrm{A}$ horizon). Post-fire values are italicised acidic as would be expected from a pine forest soil developed over these lithologies. The $\mathrm{pH}$ values show an overall slight increase after the fire but only by $1-2$ decimal points on average. Organic matter content in the upper $(0-1 \mathrm{~cm})$ soil showed a slight, though non-significant decline postcompared with pre-fire, but it remained significantly higher in the upper $(0-1 \mathrm{~cm})$ than lower $(1-5 \mathrm{~cm})$ soil (Fig. 3; Table 2), as might be expected in a typical soil profile. The lower soil, on the other hand, showed a slight, non-significant overall rise in organic matter content following the fire. The non-significant differences can be attributed to natural variability in the soil. For soil moisture, there is only a slight drop following the fire, from an average of $11.8-11.4 \%$ and a median of $12.3-10.5 \%$. Average and median bulk density remained the same after the fire, while total porosity calculations showed slight increases in average and median values. In all cases, these slight differences are not statistically significant (Table 2).

Tree mortality following the fire was estimated to be $11 \%$, and scorching of tree bark was restricted to a depth of no more than $1 \mathrm{~mm}$.

\section{Discussion}

The results clearly demonstrate that the prescribed fire did not cause any significant changes in the mineral soil properties investigated. Although there are differences in these parameters between depths (especially $\mathrm{pH}$ and organic matter), these differences can be attributed to pre-fire natural variability in the soil profile. The only parameter in this investigation that showed any statistically significant difference between pre- and post-fire was the weight of ground cover per unit area, from a mean of $4.8 \mathrm{~kg} \mathrm{~m}^{-2}$ (equivalent to $48.1 \mathrm{t} \mathrm{ha}^{-1}$ ) pre-fire to just $0.2 \mathrm{~kg} \mathrm{~m}^{-2}$ (or $2.1 \mathrm{t} \mathrm{ha}^{-1}$ ) post-fire in the form of litter (pre-fire) or litter and ash (post-fire) (see Table 1). The pre-fire potential fuel load was relatively high, but this is still considerably less than estimates made from a shrub site in central Portugal, as would be expected given the lack of a competing tree canopy (Shakesby et al. 2013). This change in the amount of pre-fire to postfire material represents an $85 \%$ reduction in the combustible material on the forest floor. After the fire, unburned forest floor fuel and any remaining ash contained therein (i.e. charred biomass and mineral residue (Bod'i et al. 2014) were not considered separately, so that this change must actually represent an underestimate of the removal of combustible material. Thus the prescribed fire resulted in a significant and important reduction in the potential fuel load, as was intended. For the other parameters, pre- and post-fire values are remarkably similar overall (Table 1). 

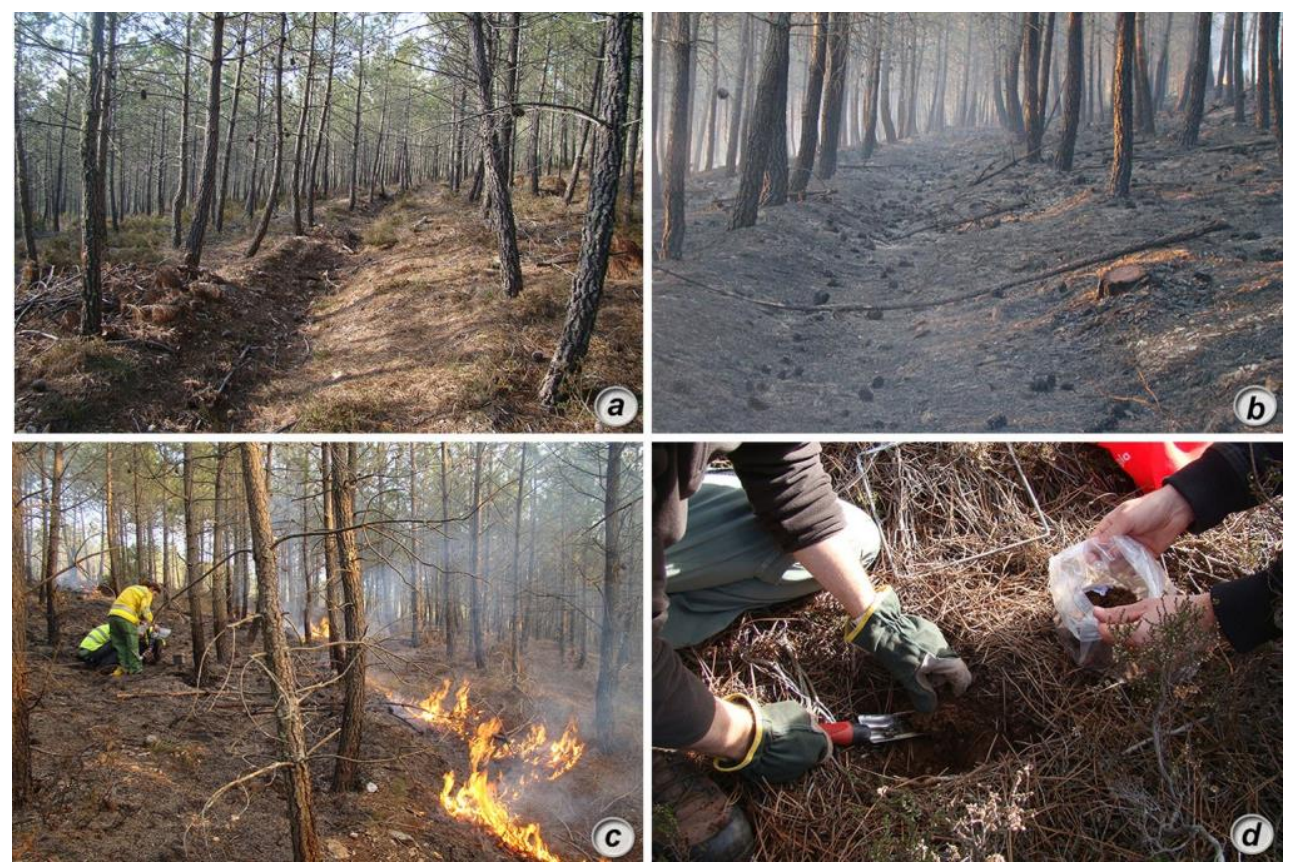

Fig. 2 Images of the field site, fire and sampling: a site conditions before the fire; $b$ site conditions after the fire; $c$ prescribed fire in progress (note the limited height of the flames); d soil sampling

Fig. 3 Frequency distribution of soil properties before and after the prescribed fire. The red lines represent the median values (Q2), blue boxes encompass the data from the 25th percentile (lower quartile Q1) to the 75th percentile (upper quartile Q3), and the whiskers represent the minimum and the maximum values excluding outliers. Outliers are represented as red crosses outside the whiskers and are defined as data points that are either more than 1.5 times the interquartile range (the length of the rectangle) above $\mathrm{Q} 3$ or more than 1.5 times the interquartile range below Q1
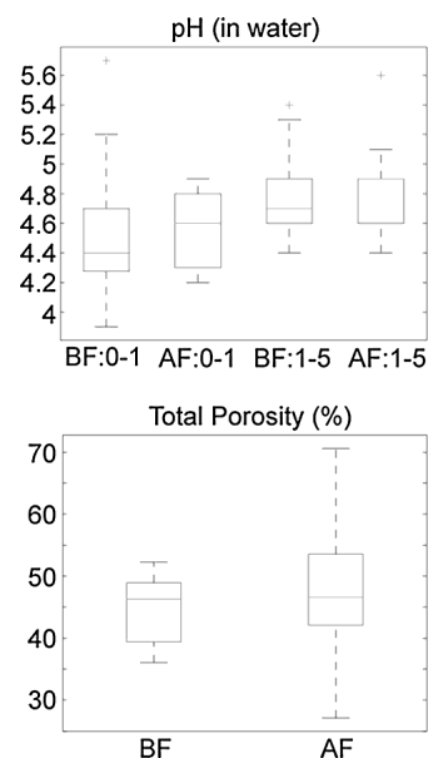

BF
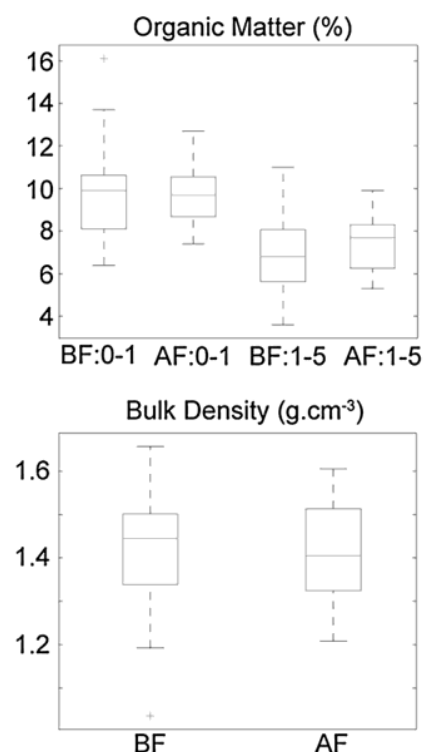
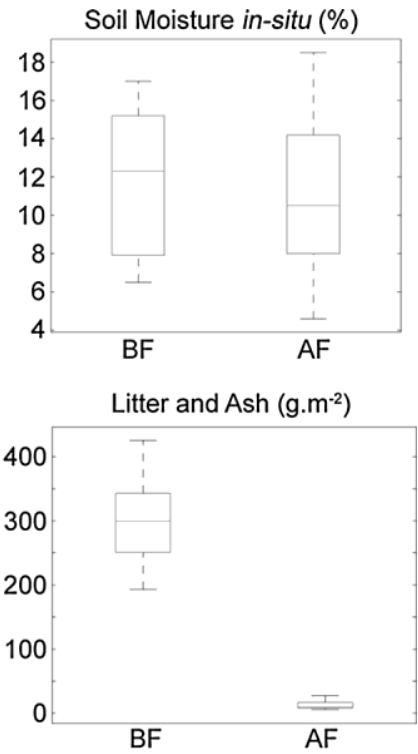

Other research has been shown that in a number of cases the impact of prescribed fire is not only measurable, but might also be damaging, particularly if carried out repeatedly (e.g. Campo et al. 2006; González-Pelayo et al. 2010). Given that such management might need to be applied on a relatively frequent basis in order to maintain a sufficiently low fuel load (Cassagne et al. 2011; Marino et al. 2011), especially under expected future increased summer temperatures causing probably greater wildfire risk (Bad'ia and Mart'́1 2008; Harding et al. 2009), this possibility of a substantial impact might apply throughout much of the Mediterranean region. However, differences between the Tresminas study site examined here and previous studies in the Mediterranean with respect to vegetation type and prescribed fire procedures need to be considered. All previous published studies in the region known to the authors were carried out on grassland and shrub vegetation, where there were typically few concerns about flame heights so that greater burn intensity, higher soil temperatures and more complete removal of biomass 
Table 2 Kruskal-

Wallis

ANOVA test results for soil parameters: (a) two-way ANOVA for both 'burn effect' (pre- versus post-burn) and 'soil depth effect' $(0-1 \mathrm{~cm}$ versus 1-5 cm where applicable) factors, and (b) one-way AINUVA Ior ourn eIIect Iactor

\begin{tabular}{|c|c|c|c|c|c|c|}
\hline \multirow{6}{*}{$\begin{array}{l}\text { Table } 2 \text { Kruskal- } \\
\text { Wallis } \\
\text { ANOVA test results for soil } \\
\text { parameters: (a) two-way } \\
\text { ANOVA for both 'burn effect' } \\
\text { (pre- versus post-burn) and 'soil } \\
\text { depth effect' ( } 0-1 \mathrm{~cm} \text { versus } \\
1-5 \mathrm{~cm} \text { where applicable) } \\
\text { factors, and (b) one-way }\end{array}$} & Kruskal-Wallis & Sum sq. & $\mathrm{df}$ & Mean sq. & Chi-sq & $p$ value \\
\hline & $\mathrm{pH}$ & & & & & \\
\hline & Burn effect & 503.3 & 1 & 503.3 & 1.51 & 0.2241 \\
\hline & Soil depth effect & $4,998.4$ & 1 & $4,998.4$ & 14.96 & 0.0003 \\
\hline & Interaction & 208.3 & 1 & 208.3 & 0.62 & 0.4327 \\
\hline & Error & $21,378.9$ & 64 & 334.0 & & \\
\hline \multirow{22}{*}{ AINUVA Ior burn eIIect ractor } & Total & $27,088.9$ & 67 & & & \\
\hline & OM & & & & & \\
\hline & Burn effect & 76.2 & 1 & 76.2 & 0.30 & 0.5837 \\
\hline & Soil depth effect & $10,033.5$ & 1 & $10,033.5$ & 39.92 & 0.0000 \\
\hline & Interaction & 52.9 & 1 & 52.9 & 0.21 & 0.6478 \\
\hline & Error & $16,087.3$ & 64 & 251.4 & & \\
\hline & Total & $26,249.9$ & 67 & & & \\
\hline & SM & & & & & \\
\hline & Burn effect & 11.8 & 1 & 11.8 & 0.12 & 0.7331 \\
\hline & Error & $3,182.0$ & 32 & 99.4 & & \\
\hline & Total & $3,193.8$ & 33 & & & \\
\hline & Porosity & & & & & \\
\hline & Burn effect & 11.8 & 1 & 11.8 & 0.12 & 0.7331 \\
\hline & Error & $3,182.0$ & 32 & 99.4 & & \\
\hline & Total & $3,193.8$ & 33 & & & \\
\hline & Bulk density & & & & & \\
\hline & Burn effect & 11.8 & 1 & 11.8 & 0.12 & 0.7331 \\
\hline & Error & $3,182.0$ & 32 & 99.4 & & \\
\hline & Total & $3,193.8$ & 33 & & & \\
\hline & Litter/ash weight & & & & & \\
\hline & Burn effect & 256.0 & 1 & 256.0 & 42.67 & 0.0000 \\
\hline & Error & 84.0 & 14 & 6.0 & & \\
\hline $\begin{array}{l}O M \text { organic matter, } S M \text { soil } \\
\text { moisture }\end{array}$ & Total & 340.0 & 15 & & & \\
\hline
\end{tabular}

$O M$ organic matter, $S M$ soil moisture

often occurred (e.g. Soto et al. 1994). Furthermore, many of these studies were carried out in relatively dry parts of the Mediterranean where post-fire vegetation recovery is slow. Consequently, these areas would be expected to be at greater risk of erosion for longer during the post-fire 'window of disturbance' (Prosser and Williams 1998; Shakesby and Doerr 2006) when vegetation cover was more sparse than at the relatively wet Tresminas site where vegetation recovery is comparatively rapid. However, rapid vegetation recovery at the Tresminas site would mean that fuel reduction burns would need to be carried out on a more frequent basis in order to maintain a low combustible biomass on the forest floor (Shakesby et al. 2013). The cumulative effect of repeated prescribed fires in Mediterranean forest plantations requires further research. Moreover, given the rugged nature of the terrain where many of the tree plantations in Portugal occur, it would be useful to carry out a monitoring programme of the impact of prescribed fire on soil structure, soil quality and soil loss in a pine stand on a comparatively steep slope to determine whether a minimal or low impact on the soil, soil erosion and runoff also applies under these circumstances.

Notwithstanding these concerns, the results of this single prescribed burn undertaken in favourable conditions and on virtually flat terrain indicate that the significant reduction in the fuel load by the use of strictly controlled prescribed fire in pine plantations had no measured detrimental effect on the soil.

Off-site impacts of prescribed burning, such as air pollution and downstream water quality effects with their implications for small mammals and reptiles (Miranda et al. 2010) as well as for drinking water supply have not been considered in this study, and indeed there has been little research elsewhere into this topic. This research gap needs to be addressed in the future.

\section{Concluding remarks}

Comparison of pre- and post-fire results for selected soil characteristics ( $\mathrm{pH}$, total porosity, moisture content, bulk 
density, organic matter content, litter and ash quantity) demonstrates that any detectable impact on the soil in this study carried out in a Pinus pinaster plantation in NW Portugal was restricted to a reduction, as desired, in the overall quantity of cover in the form of combustible litter. These results provide for the first time confirmation of the belief that, provided it is carried out according to existing strict guidelines, prescribed fire in pine plantations under wet Mediterranean conditions can have the desired effect of reducing the fuel load while leaving the soil essentially unaffected. This is an important finding because until now this has only been assumed, and not demonstrated. This study, however, was undertaken on a relatively low-angled slope, and it remains to be explored whether there would be are any soil erosion or downstream water quality implications associated with controlled burning of this type if carried out in steeper terrain.

Acknowledgments The authors wish to thank A. Vivas, E. Carvalho and L. Dinis of the AFN (Portuguese Forestry Service), who provided the operational facilities and some of the data needed to illustrate the present study. They are also grateful to all the undergraduate students from ISEP and FCUP involved in both field and laboratory work. This study was partially financed by FEDER-EU COMPETE Funds and the Portuguese Foundation for the Science and Technology, FCT (HIC, JT: PEst-C/CTE/UI4035/2014; JEM: PEstOE/CTE/UI0039/2014), and by the LABCARGA|ISEP re-equipment programme (IPP-ISEP|PAD'2007/08). AMC, RAS and SHD acknowledge the financial support provided by the British Council 'Treaty of Windsor' Travel Support Fund. We thank the anonymous reviewers for their constructive comments, which helped to improve the clarity of the manuscript.

\section{References}

AFN (2006) Plano Nacional de Defesa da Floresta Contra Incêndios (PNDFCI). Diário da República n.102, I-B Série, 26 de Maio 2006:3511-3559

Agroconsultores and COBA (1991) Carta dos solos, carta do uso actual da terra e carta de aptida o da terra do Nordeste de Portugal. UTAD-PDRITM, Vila Real

Aguilar S, Montiel C (2011) The challenge of applying governance and sustainable development to wildland fire management in Southern Europe. J Forestry Res 22:627-639

Bad'ia D, Mart 1 C (2008) Fire and rainfall energy effects on soil erosion and runoff generation in semi-arid forested lands. Arid Land Res Manage 22:93-108

Bod'1 MB, Martin D, Santín C, Doerr SH, Balfour VN, Pereira P, Mataix-Solera J, Cerda A (2014) Wildland fire ash: production, composition and eco-hydro-geomorphic effects. Earth-Sci Rev 30:103-127

Botelho HS, Rego FC, Ryan K (1998) Tree mortality models for Pinus pinaster of Northern Portugal. Proc 13th conf on fire and forest meteorology, Int Assoc Wildland Fire, pp. 235-240

Campo J, Andreu V, Gimeno E, Gonza'lez O, Rubio JL (2006) Occurrence of soil erosion after repeated experimental fires in a Mediterranean environment. Geomorphology 82:376-387

Carter M, Foster CD (2004) Prescribed burning and productivity in southern pine forests: a review. Forest Ecol Manage 191:93-109
Cassagne N, Pimont F, Dupuy JL. Linn RR, Marell A, Oliveri C, Rigolot E (2011) Using a fire propagation model to assess the efficiency of prescribed burning in reducing the fire hazard. Ecol Model 222:1502-1514

Conover WJ, Iman RL (1981) Rank transformations as a bridge between parametric and nonparametric statistics. Am Statistician 35:124-129

Fernandes PM, Botelho HS (2003) A review of prescribed burning effectiveness in fire hazard reduction. Int $\mathrm{J}$ Wildland Fire 12:117-128

Fernandes P, Botelho H (2004) Analysis of the prescribed burning practice in the pine forest of northwestern Portugal. J Env Manage 70:15-26

Gonza lez-Pelayo O, Andreu V, Gimeno-Garc'́a E, Campo J, Rubio JL (2010) Rainfall influence on plot-scale runoff and soil loss from repeated burning in a Mediterranean-shrub ecosystem, Valencia, Spain. Geomorphology 118:444-452

Harding A, Palutikof J, Holt T (2009) The climate system. In: Woodward J (ed) The physical geography of the Mediterranean. Oxford University Press, Oxford, pp 69-88

Hendershot WH, Lalande H, Duquette M (2006) Soil reaction and exchangeable acidity. In: Carter MR, Gregorich EG (eds) Soil sampling and methods of analysis, 2nd edn, Can Soc Soil Sci, $1204 \mathrm{p}$

International Organization of Standardization (1993) Soil quality. Determination of dry matter and water content on a mass basisgravimetric method. ISO 11465: 1993. International Organization of Standardization, Geneva, 3 p

International Organization of Standardization (1995) Soil quality. Determination of organic and total carbon after dry combustion (elementary analysis). ISO 10694: 1995. International Organization of Standardization, Geneva, $7 \mathrm{p}$

International Organization of Standardization (2002) Soil quality Sampling. Part 1: Guidance on the design of sampling programmes. ISO 10381-1:2002. International Organization of Standardization, Geneva, 33 p

International Organization of Standardization (2002) Soil quality. Sampling. Part 1: Guidance on the sampling techniques. ISO 10381-2:2002. International Organization of Standardization, Geneva, 23 p

International Organization of Standardization (2006) Soil quality. Pre-treatment of samples for physico-chemical analysis. ISO 11464: 2006. International Organization of Standardization, Geneva, $11 \mathrm{p}$

IUSS Working Group WRB (2006) World reference base for soil resources 2006. World Soil Resources Reports No. 103. FAO, Rome

Lix LM, Keselman JC, Keselman HJ (1996) Consequences of assumption violations revisited: a quantitative review of alternatives to the one-way analysis of variance F-test. Rev Educational Res 66:579-619

Marino E, Guijarro M, Hernando C, Madrigal J, D'́ez C (2011) Fire hazard after prescribed burning in gorse shrubland: implications for fuel management. J Env Manage 92:1003-1011

Meira-Castro A, Carvalho JP, Ribeiro S (2011) Prescribed burning impact on forest soil properties: a fuzzy boolean nets approach. Env Res 111:199-204

Meira-Castro A, Carvalho JP, Meixedo JP (2012) A qualitative description of soil parameters variation due to a prescribed fire in Portuguese northwestern forests using Fuzzy Boolean Nets: the case study of Cabreira mountain. Geoderma 191:89-96

Meira-Castro A, Shakesby RA, Espinha Marques J, Santos N, Smid M, Meixedo JP, Teixeira T, Chamine' HI, Doerr SH (2014) Insignificant impact of prescribed fire on surface soil in a Pinus pinaster plantation, northern Portugal. Flamma, Bolet'in de Fuegored (SI: Fire effects on soil physical properties) $\quad$ 5:83-85 
Miranda AI, Martins V, Cascao P, Amorim JH, Valente J, Tavares R, Borrego C, Tchepel O, Ferreira AJ, Cordeiro CR, Viegas DX, Robeiro LM, Pita LP (2010) Monitoring of firefighters' exposure to smoke during fire experiments in Portugal. Envir Int 36:736-745

Moreira F, Delgado A, Ferreira S, Borralho R, Oliveira N, Iná cio M,

Sande-Silva J, Rego F (2003) Effects of prescribed fire on vegetation structure and breeding birds in young Pinus pinaster stands of northern Portugal. Forest Ecol Manage 184:225-237

Pausas JG, Llovet J, Rodrigo A, Vallejo VR (2008) Are wildfires a disaster in the Mediterranean basin? A review. Int J Wildland Fire 17:713-723

Prosser IP, Williams L (1998) The effect of wildfire on runoff and erosion in native Eucalyptus forest. Hydrol Proc 12:251-265

Rodrigues J (1999) A conspirac,ão solar do Padre Himalaya: esboc so biográfico dum portuguess pioneiro da Ecologia. Cooperativa Árvore, $287 \mathrm{p}$

Salgueiro A (2010) The Portuguese National Programme on suppression fire: GAUF team actions. In: Montiel C, Kraus D (eds) Best practices of fire use: prescribed burning and suppression fire programmes in selected case-study regions in Europe. European Forest Institute, Brussels, pp 123-136
Sant'Ovaia H, Ribeiro MA, Martins H, Noronha F (2011) Not'icia explicativa da Carta Geológica de Portugal, escala 1:50.000, Folha 6-D (Vila Pouca de Aguiar). Laboratório Nacional de Engenharia e Geologia, Lisboa, 37 p

Shakesby RA, Doerr SH (2006) Wildfire as a hydrological and geomorphological agent. Earth-Sci Rev 74:269-307

Shakesby RA, Bento CPM, Ferreira CSS, Ferreira AJD, Stoof CR, Urbanek E, Walsh RPD (2013) Impacts of prescribed fire on soil loss and soil quality: an assessment based on an experimentallyburned catchment in central Portugal, Catena. doi: 10.1016/j. catena.2013.03.012. (online first/in press)

Soto B, Basanta R, Benito E, Pérez R (1994) Runoff and erosion from burnt soils in Northwest Spain. In: Sala M, Rubio JL (eds) Soil erosion as a consequence of forest fires. Geoforma Ediciones, Logron o, pp 91-98

Úbeda X, Lorca M, Outeiro LR, Bernia S, Castellnou M (2005) Effects of prescribed fire on soil quality in Mediterranean grassland (Prades Mountains, north-east Spain). Int J Wildland Fire 14:379-384 